Editorial

\title{
Tantangan Harmonisasi Pengetahuan Lokal, Sains dan Kebijakan Publik dalam Agenda Pembangunan di Era Industri 4.0
}

\author{
Agung Wibowo ${ }^{1,2,{ }^{*}}$, Soaloon Sinaga ${ }^{1,2}$, Yetrie Ludang ${ }^{1,2}$, Indrawan Permana ${ }^{1,2}$, Misrita $^{1,2}$ \\ ${ }^{1}$ Program Pascasarjana Universitas Palangka Raya \\ ${ }^{2}$ Dewan redaksi Journal of Environment and Management \\ *Korespondensi: Agung Wibowo (Email: agungwi@for.upr.ac.id)
}

\section{ERA BARU INDUSTRI 4.0}

Zaman terus berubah. Bahkan perubahannya semakin cepat dibandingkan era sebelumnya. Ketua Eksekutif Forum Ekonomi Dunia, Klaus Schwab, menyatakan bahwa revolusi teknologi yang terjadi saat ini telah mengubah perilaku dan cara hidup dalam skala, cakupan, dan kompleksitas yang belum pernah dialami manusia (Morrar et al., 2017). Era ini dikenal sebagai "Industry 4.0", yaitu suatu istilah yang dimunculkan pada Hanover Fair di Jerman tahun 2011, sebagai lonceng kewaspadaan agar negara tersebut segera mempersiapkan strategi mitigasi atas meningkatnya persaingan dari luar negeri dan untuk mendiferensiasi industri Jerman dan Uni Eropa dari pasar internasional. Dengan makna yang indentik, istilah ini di Inggris disebut revolusi industri keempat, dan di Amerika Serikat dikenal dengan industri yang terkoneksi.

Kemajuan teknologi pada era industri 4.0 tidak terbantahkan. Namun teknologi saja tidak dapat membuat perubahan yang signifikan, meski sebagian besar komponennya telah lahir sejak 30 yang lalu. Akselerasi perubahan terjadi justru ketika teknologi tersebut bertemu dengan teknologi informasi dan komunikasi (information and communication technology/ ICT) dan murahnya harga perangkat lunak dan keras (Klingenberg and Antunes, 2017). Dengan komunikasi melalui internet, interaksi yang terjadi bukan hanya antar manusia (costumer to costumer/C2C), tetapi juga antar manusia dengan mesin (costumer to machine/C2M), dan antar sesama mesin (machine to machine/M2M) (Roblek et al., 2016). Pertukaran informasi sebagai bagian dari kerja atau produksi terjadi sepanjang hari di berbagai wilayah. Semua pihak dipaksa untuk meningkatkan daya saing melalui penggunaan perangkat cerdas (Heck and Rogers, 2014). Perlahan namun pasti sebagian besar perangkat dan proses konvensional bertransformasi ke bentuk yang disebut elektronik, online, digital, virtual dan siber. Masyarakat Indonesia, contohnya, saat ini sudah familiar dengan istilah KTP elektronik, belanja online, belajar online, media online, ojek online, perpustakaan digital, dunia virtual, atau kejahatan siber.

Kemajuan dan kecepatan perkembangan teknologi bagai pisau bermata dua yang mempunyai sisi tajam dan tumpul. Teknologi informasi dan komunikasi dapat memangkas rantai pasok yang panjang dan memungkinkan produsen bertransaksi langsung dengan konsumen di pasar online, sehingga dapat menekan biaya distribusi, dan dan menjadikan harga produk lebih murah. Di sisi lain teknologi industri 4.0 memberikan dampak negatif bagi perusahaan yang tidak adaptif (Fonna, 2019). Meningkatnya produksi dan konsumsi barang dan jasa telah menimbulkan kegusaran terhadap penggunaan faktor produksi, utamanya substitusi tenaga kerja manusia oleh mesin atau robot, dan meningkatkan ekstraksi sumberdaya alam (Jabbour et al., 2020). Diperkirakan bahwa peningkatan jumlah pabrik pintar (smart factory) di periode mendatang akan menggusur pekerja tidak terampil (Uğurlu and Pajo, 2019).

Era industri 4.0 dengan segala kompleksitasnya memberikan harapan bagi perbaikan atas ketimpangan sosial-ekonomi, permasalahan perubahan iklim, meningkatnya degradasi lingkungan, dan tingginya urbanisasi yang menjadi permasalahan global para era sebelumnya (Stock et al., 2018). Hal tersebut telah menjadi cita-cita bersama dan disepakati dalam Sidang Umum Perserikatan Bangsa-Bangsa yang menghasilkan kesepakatan Agenda 2030 atau yang dikenal dengan Sustainable Development Goals (SDGs). Agenda 2030 memberi landasan bagi transformasi ekonomi global menuju pembangunan berkelanjutan dan harus diterapkan oleh negara-negara di seluruh dunia (United Nations, 2015). Merespons hal tersebut, pada tahun 2017 Uni Eropa merilis kerangka kerja untuk aksi terhadap masyarakat (people), bumi (planet), kesejahteraan (prosperity) dan perdamaian (peace). Kesepakatan para pemimpin dunia untuk merealisasi agenda pembangunan 
yang berkelanjutan memberikan angin segar bagí terciptanya keadilan yang selama ini diperjuangkan pihak -pihak yang lemah secara politis.

Patut dicatat bahwa kebijakan di level internasional harus berhadapan dengan berbagai kepentingan sebelum dapat diimplementasikan di suatu negara. Oleh karena itu, kebijakan publik (dalam konteks ini termasuk produk hukum seperti Undang-Undang dan turunannya) pada level internasional, regional, nasional dan subnasional sesungguhnya merupakan transaksi kepentingan para aktor yang menghendaki maksimalisasi keuntungan (benefit maximisation). Inilah fokus dari kebijakan publik; yaitu resolusi atas kepentingan yang multi arah (Krott, 2005). Mengetahui proses penyusunan suatu kebijakan akan membantu kita memahami untuk siapa sebenarnya kebijakan itu dibuat.

\section{KONTESTASI KUASA DAN KEPENTINGAN DALAM PENYUSUNAN KEBIJAKAN PUBLIK}

Suatu kebijakan publik dihasilkan dari empat tahap proses yang disebut policy cycle, yaitu penentuan agenda (agenda setting), perumusan kebijakan dan pengambilan keputusan (policy formulation and decision-making), penerapan kebijakan (implementation), dan evaluasi dan penghentian kebijakan (evaluation and termination) (Jann and Wegrich, 2017). Tahapan penentuan agenda hingga pengambilan keputusan idealnya melibatkan seluruh pemangku kepentingan yang mempengaruhi dan atau akan dipengaruhi oleh kebijakan tersebut. Para pihak yang biasa terlibat dalam proses pembuatan kebijakan di bidang lingkungan hidup dan sumberdaya alam adalah birokrasi internasional (misal: PBB dan seluruh organisasi dan badannya), kalangan bisnis, baik multinasional, nasional, maupun lokal, komunitas ilmiah (misalnya lembaga penelitian dan perguruan tinggi), lembaga keuangan dan donor (misalnya IMF, ADB, Ausaid, UKAID), pemerintah baik pusat maupun daerah, masyarakat lokal, masyarakat adat, serikat pekerja, organisasi non pemerintah, dan media massa.

Kedudukan para pihak (disebut juga: stakeholder, aktor, pemangku kepentingan) tersebut idealnya sejajar (equal), dalam arti mereka memiliki hak dan kedudukan yang sama dalam menyampaikan pendapat dan untuk diakomodasi kepentingannya. Akan tetapi pada faktanya kedudukan para pemangku kepentingan seringkali tidak setara; ada pihak yang lebih berkuasa (powerful) dan ada yang kurang berkuasa (powerless). Kuasa (power) adalah kemampuan untuk mengubah perilaku pihak lain tanpa mempertimbangkan apakah pihak lain tersebut menyetujuinya atau tidak (Krott et al., 2014). Kuasa bersumber dari kemampuan untuk memaksa (contohnya hak menjatuhkan hukum yang dimiliki oleh pihak berwenang/pemerintah), kemampuan untuk memberi insentif atau disinsentif, (misalnya memberikan bantuan finansial atau mengenakan tarif tertentu), dan pengetahuan yang dimiliki secara eksklusif (misalnya kemampuan menganalisis kandungan kimia suatu zat). Semakin banyak sumber kuasa dimiliki oleh suatu pihak semakin besar peluang pihak tersebut mempengaruhi bentuk kebijakan yang akan diputuskan.

Bentuk kebijakan yang dihasilkan suatu proses kebijakan dipengaruhi oleh kepentingan (interest) aktor dengan kuasa terbesar, baik dia terlibat secara langsung maupun tidak dalam proses pembentukan kebijakan tersebut. Untuk memperbesar kuasa, aktor-aktor yang memiliki kesamaan kepentingan akan menggabungkan diri kedalam suatu aliansi (alliance). Selanjutnya, transaksi kepentingan tidak lagi terjadi antar-aktor, namun melebar menjadi antar-aliansi. Pada level internasional, kumpulan aliansi yang memiliki kesamaan kepentingan saling berkomunikasi, dan membentuk suatu rezim (regime) dalam rangka membuat prinsip, norma, tata aturan, dan prosedur pengambilan keputusan yang ditaati bersama (Krasner, 1983).

Gellert (2010) menyebutkan bahwa paradigma pembangunan di Indonesia pada masa Orde Baru (19661998) mengikuti pola rezim ekstraktif. Gellert (2010) menyatakan bahwa rezim ekstraktif ditandai oleh ketergantungannya pada ekstraksi berbagai sumber daya alam dalam pembentukan tatanan ekonomi dan politik yang juga didukung oleh kekuatan global dan regional. Berdasarkan hal ini dapat dipahami mengapa ekstraksi sumberdaya alam seperti hutan, perikanan, tambang, minyak bumi dan gas terjadi secara masif di masa Orde Baru. Pemerintah menunjuk 120 hektar lahan atau $62 \%$ total daratan sebagai hutan negara tanpa proses akuisisi yang tepat (Galudra and Sirait, 2009). Hegemoni yang kuat dari keluarga Soeharto, militer, partai politik pendukung pemerintah dan konglomerat ChinaIndonesia berhasil mengekstraksi sebagian besar lahan hutan dan meningkatkan produk domestik bruto dan pendapatan pemerintah, menciptakan lapangan pekerjaan dan mempromosikan pembangunan di luar Jawa (Wibowo dan Giessen, 2015). Namun pada periode berikutnya, kebijakan pemerintah yang bersifat ekstraktif ini banyak dikritik karena menyebabkan kerusakan lingkungan seperti tingginya tingkat deforestasi, illegal logging, kebakaran hutan tahunan, hilangnya keanekaragaman hayati, dan memicu konflik lahan.

Permasalahan lingkungan yang diwariskan rezim ekstraktif yang dianut negara-negara berkembang pada masa itu menumbuhkan kesadaran global untuk menciptakan paradigma pembangunan yang lebih adil dan berkelanjutan. Pada Konferensi PBB tentang Lingkungan dan Pembangunan atau yang dikenal dengan KTT Bumi di Rio de Jeneiro tahun 1992 dihasilkan dokumen Agenda 21 yang merupakan cetak biru bagi pelaksanaan pembangunan berkelanjutan, dan Deklarasi Rio yang menjadi komitmen politik untuk melaksanakan Agenda 21 (Jhamtani, 2017). Semenjak itu menggemalah konsep pembangunan yang menyeimbangkan aspek ekonomi, ekologi dan sosial. 
Konsep pembangunan berkelanjutan menjadi amunisi baru kalangan konservasionis untuk memperjuangkan hak -hak masyarakat adat dan kelestarian lingkungan yang telah lama diabaikan. Agenda 21 dianggap mengakui keunggulan cara hidup harmonis dan pengetahuan lokal yang dipraktikan selama ratusan tahun oleh masyarakat adat di berbagai belahan dunia. Kelompok pecinta lingkungan dan masyarakat adat beraliasi dan memainkan peranan dalam proses pengambilan kebijakan terkait pemanfaatan sumberdaya alam yang selama ini didominasi para birokrat dan kalangan bisnis (investor).

\section{PERANAN MASYARAKAT ILMIAH}

Kebijakan publik akan mempengaruhi masyarakat secara luas dalam waktu yang panjang. Bahkan dampaknya bisa dirasakan hingga beberapa generasi. Oleh karena itu perumusan suatu kebijakan publik memerlukan pengkajian yang mendalam dari berbagai sudut keilmuan serta melibatkan pihak-pihak yang terkait. Pada titik ini masyarakat ilmiah -sebagai pihak yang dianggap memiliki otoritas terhadap sains dan ilmu pengetahuan- dapat berkontribusi memberikan masukan sehingga kebijakan yang dihasilkan memiliki basis argumen yang kuat dan bisa dipertanggung-jawabkan.

Keterlibatan masyarakat ilmiah dalam pembuatan kebijakan tidak selalu mewujud dengan kehadiran mereka dalam rapat-rapat di lembaga legislatif dan eksektif. Lebih dari itu, masyarakat ilmiah dapat memberikan peringatan dini (early warning) tentang suatu hal sehingga pihakpihak yang berkepentingan dapat melakukan antisipasi secara tepat. Mereka juga dapat menarik perhatian publik sehingga isu yang mereka diskusikan mengkristal dan menjadi agenda kebijakan publik.

Masyarakat ilmiah memiliki tradisi yang khas dalam mengkomunikasikan pemikirannya. Pemikiran-pemikiran maupun hasil penelitian mereka ditulis dengan kaidahkaidah yang baku, menggunakan metode yang telah teruji, dan mendapatkan telaah oleh ahli selingkung sebelum disajikan dalam jurnal-jurnal ilmiah.

Journal of Environment and Management (JEM) yang Anda baca saat ini adalah bentuk kontribusi nyata Program Pascasarjana Universitas Palangka Raya (PPs UPR) dalam mendiseminasikan hasil-hasil penelitian dan pemikiran mahasiswa dan dosen PPs UPR. JEM diharapkan menjadi media transaksi pengetahuan yang kredibel dan mampu memicu tumbuhnya diskusi-diskusi akademik yang sehat, terutama yang berkaitan dengan isu pembangunan lingkungan hidup dan manajemen di Kalimantan Tengah. JEM menerima dan berkeinginan kuat untuk mempublikasikan hasil penelitian, telaah ilmiah, maupun komunikasi singkat dari mahasiswa pascasarjana, dosen dan peneliti dari seluruh Indonesia.

Akhirnya kami mengucapkan selamat kepada para penulis yang karyanya berhasil terbit pada edisi pendana JEM. Kami juga menantikan kontribusi kolega akademik lainnya. Salam publikasi!

\section{DAFTAR PUSTAKA}

Fonna, N., 2019. Pengembangan Revolusi Industri 4.0 dalam Berbagai Bidang. GUEPEDIA.

Galudra, G. and Sirait, M., 2009. A discourse on Dutch colonial forest policy and science in Indonesia at the beginning of the 20th century. International Forestry Review, 11(4), pp.524-533.

Gellert, P.K., 2010. Extractive regimes: toward a better understanding of Indonesian development. Rural Sociology, 75(1), 28-57.

Heck, S. and Rogers, M., 2014. Are you ready for the resource revolution. McKinsey Quarterly, 2, 32-45.

Jabbour, C.J.C., Fiorini, P.D.C., Wong, C.W., Jugend, D., Jabbour, A.B.L.D.S., Seles, B.M.R.P., Pinheiro, M.A.P. and da Silva, H.M.R., 2020. First-mover firms in the transition towards the sharing economy in metallic natural resource-intensive industries: Implications for the circular economy and emerging industry 4.0 technologies. Resources Policy, 66, p.101596.

Jann, W. and Wegrich, K., 2017. Theories of the policy cycle. In F. Fischer, G. J. Miller, M. S. Sidney (Eds.). Handbook of public policy analysis (pp. 69-88). Routledge.

Jhamtani, H., 2017. Pembangunan berkelanjutan di tengah globalisasi: adakah harapan?. Global: Jurnal Politik Internasional, 5(1), 1-8.

Klingenberg, C. and Antunes, J., 2017. Industry 4.0: what makes it a revolution. EurOMA 2017, 1-11.

Krasner, S.D., 1983. International regimes. Cornell University Press.

Krott, M., 2005. Forest policy analysis. Springer Science \& Business Media.

Krott, M., Bader, A., Schusser, C., Devkota, R., Maryudi, A., Giessen, L. and Aurenhammer, H., 2014. Actor-centred power: The driving force in decentralised community based forest governance. Forest Policy and Economics, 49, pp.34-42.

Morrar, R., Arman, H. and Mousa, S., 2017. The fourth industrial revolution (Industry 4.0): A social innovation perspective. Technology Innovation Management Review, 7(11), 12-20.

Roblek, V., Meško, M. and Krapež, A., 2016. A complex view of industry 4.0. Sage Open, 6(2), p.2158244016653987.

Stock, T., Obenaus, M., Kunz, S. and Kohl, H., 2018. Industry 4.0 as enabler for a sustainable development: A qualitative assessment of its ecological and social potential. Process Safety and Environmental Protection, 118, 254-267.

Uğurlu, K. and Pajo, A., 2019. A Measure Against Unemployment Problem Expected to Occur by Industry 4.0: Cittaslow. http://acikerisim.kirklareli.edu.tr:8080/ xmlui/handle/20.500.11857/1153

United Nations, 2015. Transforming our world: The 2030 agenda for sustainable development. General Assembley 70 session.

Wibowo, A. and Giessen, L., 2015. Absolute and relative power gains among state agencies in forest-related land use politics: The Ministry of Forestry and its competitors in the REDD+ Programme and the One Map Policy in Indonesia. Land Use Policy, 49, 131-141. 